\title{
Miért ésszerü maradni, ha egyszer nem az? - Szempontok az „immobilitás-kutatás” feldolgozásához és elemzéséhez
}

\author{
KRÉMER BALÁZS ${ }^{1}$
}

\begin{abstract}
ABSZTRAKT
A dolgozat teoretikus, spekulatív szempontokat vesz számba annak magyarázatához, hogy vajon a falun élők, különösen a magasan képzett fiatal falusiak vajon miért maradnak (költöznek vissza) a falujukba(n) a tanulmányaik befejezése után. Az elvi magyarázatokra amiatt van szükség, mert a szokásos előfeltevések szerint a falun rosszabbak a munkalehetőségek, alacsonyabbak a keresetek, szegényesebbek a fogyasztás, a szórakozás, a müvelödés feltételei - hasznosnak és racionálisnak az tünik, ha a fiatalok a gazdagabb lehetöséget kínáló városba, esetleg külföldre költöznek, ha földrajzi és társadalmi értelemben mobilak. Ezen gyakran általánosított feltételezéssel szemben lehetnek és vannak olyan körülmények, amelyek között mind az anyagi hasznosság érdekei, mint az elérhető társadalmi státusz megbecsültségének kilátásai alapján ésszerü választás a falun maradni, „immobilnak lenni”. Ezeket a körülményeket mint az immobilitás lehetséges magyarázatait veszi számba a tanulmány.
\end{abstract}

KULCSSZAVAK: mobilitás-immobilitás, érdek, társadalmi státusz, magyarázat

\section{ABSTRACT}

Why it is sensible to stay, if it is not? -

Insights for processing and analyzing prospects of „immobility research"

The paper takes into account theoretical, speculative considerations to explain why villagers, especially highly educated young villagers, stay (relocate) to their village after completing their studies. Explanations are needed because the usual assumptions are that the village offers poorer job opportunities, lower earnings, poorer conditions of consumption, entertainment and education than cities - it seems useful and rational for young people to move to a city (or abroad) with a richer supply of facilities; if they are geographically and socially mobile. Against this often generalized assumption, there are circumstances in which both the interests of material utility and the prospect for gaining attractive social status make it a reasonable choice to stay in the village, to be ,immobile.' These circumstances are considered as possible explanations for immobility.

KEYWORDS: mobility-immobility, interest, social status, interpretation/explanation

${ }^{1}$ Egyetemi docens, Debreceni Egyetem Szociológia és Szociálpolitika Tanszék, kremer.balazs@arts. unideb.hu 
www. metszetek.unideb.hu

\section{TEMATIKUS TANULMÁNYOK - Községekben élő immobil fiatalok}

\section{Bevezetés}

A TIPIKUS ALAPFELTEVÉS:

\section{A VÁROSIASODÁS ÉS VÁROS FELÉ TARTOZÓ MOBILITÁS}

Egy általános, ámde ki nem mondott előfeltevés:

a faluból való elköltözés hasznos és racionális

A falusi immobilitás problémája egy igen nehéz kutatási téma. Mondjuk, a mobilitás kutatásával szembeállítva az a legnagyobb nehézsége, hogy míg a mobilitás, az különféle életbevágó döntések és történések viszonylag könnyen kérdezhető és feltárható sora - addig az immobilitás története, azaz a történet, amelyben „nem történik semmi”, és ezt a „semmit” kell feltárni, értelmezni és magyarázni.

Ez a körülmény önmagában is adalék ahhoz, hogy miért szokás a mobilitást, és miért nem szokás az immobilitást kutatni, de, a társadalomtudománynak erre is van egy „önfelmentő” további magyarázata is. A XIX. század eleje óta a modernitás a fejlődés domináns elemének tekinti az urbanizáció folyamatát:

- A vidéki-falusi központú mezőgazdasággal szemben a városias ipar, később a szintén városias szolgáltatás a piacgazdaság domináns termelési ágazata.

- A gyáriparba csak akkor és azáltal lehet nagy tömegben koncentrálni a munkásságot (akármit is jelentsen ez...), ha az a közelben, elérhető távolságban lakik, ha az a városokban koncentrálódik.

- A város a hanyatló falusi mezőgazdasággal szemben a gazdasági prosperitás és a munkalehetőségek, a megélhetés gazdagabb kínálatának a világa.

- Különösen a Chicago-i Iskola (ezen belül is Ernst Burgess és Louis Wirth) nyomán, a város nemcsak a munkalehetőségek, hanem az élet szabadságának a vonzó világa: nagyobb kínálatból lehet választani társakat, fogyasztást, hitéleti és kulturális kötődéseket, szabadidő eltöltésének formáit stb. A józan érdekeit követő „szabad ember”, az individuum - az a faluból a város felé törekszik. A város mintegy vonzza a falusi lakosságot, különösen a falusi fiatalokat.

De nemcsak a város vonzásának előfeltevése tekinti „alapnak” a mobilitást, hanem a falu "taszítása” is. Kovách Imre ezt gyakran azzal a „szociál-darwinista” szentenciával rendezi el, hogy „a magyar falu túlnépesedett”, nem képes eltartani a lakosságát (Kolozsi 2018). De, ezt a szentenciát ezernyi statisztikai adattal is alá lehet támasztani: nagyobb a munkanélküliség és a közmunka, alacsonyabbak a jövedelmek, kevésbé komfortosabbak a lakások és kevésbé urbanizáltak a lakókörnyezetek stb. - mint a városban. Az embereknek az a józan érdekük, hogy meneküljenek a faluból, minimum a közeli városig, de, akár Pestig vagy külföldre is. 


\section{TEMATIKUS TANULMÁNYOK - Községekben élő immobil fiatalok}

\section{A FÖLDRAJZI MOBILITÁS ELTÉRÉSEINEK SZOCIOLÓGIAI MAGYARÁZATAI}

A fentiek következménye az, hogy a társadalomtudományi munkák a mobilitási adatokat dokumentálják, ${ }^{2}$ az elméletek a földrajzi mobilitást igyekeznek magyarázni, és az immobilitás magyarázatai legfeljebb a mobilitási magyarázatok „komplementerei". Azaz, akiknek nem sikerül interpretálni, értelmezni a mobilitását - az marad ott, ahova született, az immobil.

A társadalomtudományos értelmezések egy része társadalomtörténeti érvekkel magyarázza a mobilitás társadalmi eltéréseit. Ezek az érvek nagyrészt arra épülnek, hogy azokon a településeken, ahol meghatározó történelmi tapasztalata, szokása és hagyománya van az útra kelésnek, onnan az emberek ma is könnyebben, nagyobb arányban válnak mobillá. Ilyen térségenként és településenként eltérő mobilitási potenciált alapoz meg az, ha egy faluból

- sokan tántorogtak ki Amerikába a XIX. század fordulóján,

- a Trianon utáni „spontán betelepülés” és a II. világháború utáni, fóképp a szlovák és német nemzetiséget érintő „erőszakos kitelepítés és lakosságcsere” jelentős mobilitási tapasztalatai emlékként fennmaradtak a település kollektív emlékezetében és identitásában,

- a saját földjéből megélni képtelen kisbirtokos és napszámos réteg távolabbi szezonmunkákból, summásként egészítette ki jövedelmét a II. világháború előtt, olykor után is,

- az adott falu régebbi hagyományként specializálódott, piaci értékesítésre folytatott mezőgazdasági árutermelést (szőlő és bor, hagyma, paprika, torma és más kertészeti termékek, tenyészállatok stb.), és így a lakosság egy része maga is bekapcsolódott az árut a távolabbi piacokra eljuttató fuvarozási és kereskedelmi tevékenységbe,

- tradicionális üdülő és gyógyfürdős falvak, amelyekben a távolabbról érkezett vendégekkel a kapcsolat nemcsak a helyi vendéglátásra, hanem a viszonos látogatásokra is kiterjedt,

- valamilyen speciális szakma gyakorlása a falu sajátossága volt, és e speciális szolgáltatást, terméket távolabbi piacokon is gyakorolták (olykor e szakma valóban speciális volt, pl. Hofer Tamás és Fél Edit kutatási terepén, Átányban speciális helyi szakértelem volt a teniszpályák építése, salakozása bárhol az országban; de máskor ez nem jelentett speciális „szakmát”, pl. bizonyos falvakból nagy arányban mentek fiatal lányok városi házicselédnek),

${ }^{2}$ Az ingázás alapos elemzését a 2011. évi népszámlálási adatok alapján a KSH csak nemrég hozta nyilvánosságra (Az ingázás kiemelt célpontjai, KSH 2016.április, http://www.ksh.hu/docs/hun/xftp/idoszaki/pdf/ingazas.pdf ), a 2010 után felgyorsult nemzetközi mobilitás jelenségét Sik Endre, Hárs Ágnes, Melegh Attila, Kováts András és mások számos munkája dokumentálja. 


\section{TEMATIKUS TANULMÁNYOK - Községekben élő immobil fiatalok}

- a szocialista extenzív iparfejlesztés korszakában némely falvak a „fekete vonat" ingázó vonalán” tömegével bocsátott ki olyan ingázó városi munkásokat, akik később a város környékén, majd a városban le is telepedtek. ${ }^{3}$

Ez utóbbi, a végleges elköltözést részleges mobilitással megalapozó élettörténetet napjaink globális mobilitással foglalkozó szakirodalma is alátámasztja, pl. azzal, hogy a nemzetközi vándorlásban döntő jelentőségük van a „mobilitási pioníreknek”, a hozzájuk való látogatást követő odatelepedésnek. ${ }^{4}$

A társadalomtudományi magyarázó elméletek másik része kimondottan strukturális okokkal magyarázza a mobilitást. A magyarázó séma arra épül, hogy a mobilitási potenciál a falu társadalomszerkezetének közepén lelhető meg: akik a struktúrában fent vannak, azok ,jól elvannak”, miért is akarnának elmenni; akik meg nagyon lent vannak, azoknak nincsen elég megtakarításuk ahhoz, hogy máshol kezdhessenek új életet. Ezt a fejre állított U függvényképpel szemléltethető mobilitási potenciál-megoszlást vázolja Hajdúhadház példáján Harcsa -Kovách -Szelényi tanulmánya (1998).

Az újabb kori nemzetközi irodalomban ez a kép annyiban árnyaltabbá vált, hogy a periféria országaiból és szegényebb térségeiből a leggazdagabbak mobilitása is felerősödött - a távolabbi centrum-országok irányába. A magyarázó séma azonban ugyanaz: távolra, külföldre csak az képes lejutni, akinek a megtakarításai, a vagyona még e gazdagabb környezetben is alapot jelent az új élet elkezdéséhez.

A társadalomtudományi magyarázatok harmadik csoportja a mobilitást a hálózatok elméletéből nyeri. A gondolat gyökerei részben Manuel Castellstől eredeztethetőek, aki az adott társadalmon belüli egyenlőtlenségek döntő faktorának tekinti a hálózatokba (ezen belül is, különösen a globális hálózatokba) való bekapcsolódás képességét (Castells 2005). Ennyiben, a „hálózati bekötöttség” nemcsak mobilitási potenciál, hanem a magasabb státusz mutatója is Castells teóriájában. Ezt a viszonylag tagolatlan képet tovább árnyalja az eredetileg politológus Robert D. Putnam a civil társadalomról szóló alapvető munkájában (Putnam 2000). Fő gondolatmenetének egy mellékágán ő megkülönbözteti a befelé erősen kötő, bezárkozó „bonding” jellegű, Tönnies közösségi intimitásához hasonló „erős” kapcsolatokat, és a csoport- és osztályhatárokon átnyúlni, azokat áthidalni képes „bridging” típusú, Granowetter gyenge kapcsolataihoz hasonló társadalmi-közösségi kötelékeket. Ebben a megkülönböztetésben a kapcsolatok természete egyfajta hagyományokra alapozott közösségi jellemző, és eszerint a földrajzi távolságokat áthidaló „gyenge kapcsola-

${ }^{3}$ Ezt az ingázással a városba szokó, majd előbb az agglomerációban, később a városban letelepedő munkás képét igen expresszíven és nagy meggyőző erővel írta le Berkovits György szociográfiája: Berkovits (1978): Világváros határában, Szépirodalmi Kiadó - Magyarország felfedezése, Budapest

${ }^{4}$ A „mobility pioneering” kifejezés Sven Kesselring cikke nyomán vált általánosan elterjedté: Kesselring (2006): Pioneering mobilities: new patterns of movement and motility in a mobile world. Environment and Planning 2006/38, pp. 269-279, http://www.unisa.edu.au/siteassets/episerver-6-files/ global/eass/hri/pioneering-mobilities_kesselring-sven.pdf 


\section{TEMATIKUS TANULMÁNYOK - KöZségekben élő immobil fiatalok}

tok ereje" mobilitási erőforrásként és potenciálkánt is értelmezhető. Ugyanígy, más esetekben a hagyományok és a gazdasági/társadalmi berendezkedés sajátosságai a mobilitástól visszatartó, visszahúzó erőként is értelmezhető (Kovács 2016).

\section{Akkor miért vannak, akik maradnak?}

\section{AZ IMMOBILITÁS - MINT HÁTRÁNY ÉS KIREKESZTETTSÉG}

Előfeltevésként a mobilitás feltételezése a természetes, és egyszersmind a domináns is a szociológia területi-térségi mobilitáshoz való viszonyulásában, amihez képest, a faluban maradást, az immobilitást jellemzően átmeneti megkésettségnek tekinti (még nem költöztek el, de ez csak idő kérdése, vagy már nem fognak soha elköltözni, mert öregek, és úgyis meg fognak halni).

Vagy, még jellemzőbben: valamiféle kudarcnak, hátránynak. Mindenki, aki képes és tud, az onnan "menekül”, azt vonzza a város - és aki nem, az balszerencsés, lúzer, szerencsétlen, akinek ez valamilyen „hátrány” miatt nem jött össze.

Igazából nem tudjuk, hogy statisztikailag mennyire megalapozottak ezek az előfeltevések. Amint jeleztük, általánosságban is a társadalomkutatók érdeklődése inkább a mobilitás, mint az immobilitás megfigyelése és interpretációja felé fordult; a mobilitást, és nem az immobilitást akarták megmagyarázni, de ehhez még külön teher az, hogy saját kutatásunk választott eszközei és módszerei még a mobilitás szociológiai magyarázatához is legfeljebb sejtéseket, benyomásokat képes felvetni az interjúk és egyéb rendelkezésre álló információk alapján.

Mindezt indokolja az, hogy a kutatás nem a társadalomtudományokban szokásos tipikus, „normális” mobilitási körülmények feltárását tekinti (különösen az interjús megkérdezések) fókuszának, hanem a kivételességek és rendkívüliségek leírására és értelmezésére kell koncentrálnia. Azokat az embereket igyekszik megérteni, akik

a) falun élnek, és ott is tervezik maradni, nem akarnak elköltözni (ehhez képest leginkább olyan szerepben kérdez mobilokat is, amilyen funkciót a kontrollcsoportoknak szokás szánni).

b) Pedig, legalábbis elvileg nemhogy lehetőségeik volnának városba költözni, hanem életük során (pl. felsőfokú tanulmányaik alatt) bele is kóstoltak a városi életbe, szeretek tapasztalatokat a városi életről.

c) Azzal a nem szokványos előfeltevéssel is él a kutatás, hogy ez a megkérdezettek körében jellemzően nem valamiféle sorsszerűség, beszorultság, társadalmi kirekesztettség - hanem tudatos és szándékos döntés következménye. Ezen, a mérvadó előfeltevésekhez képest extrém, nem szokványos tudatosságok és szándékosságok körülményeit, indítékait, magyarázatait, és ha lehet, akkor okait igyekszik feltárni a kutatás. 


\section{TEMATIKUS TANULMÁNYOK - Községekben élő immobil fiatalok}

d) A háttérbe szorított extrémitások kutatásának nem a „bulvár-érdeklődés” a legfóbb szociológiai mozgatója, hanem a társadalom megismerése. Ennek egyik alapsémája az a Durkheim-i program, amely az extrémitások (pl. az anómia) megértéséből igyekszik kifejteni a normál társadalmi működésmódot (a társadalmi normák átfogó szerepét). A szociológiában nem vizsgált, de a tudományos sztereotípiákban extrémnek tekintett immobilitás megértése nagyban hozzájárulhat az átfogó társadalmi folyamatok, így a földrajzi mobilitás értelmezéséhez is. De legalább ennyire fontos az a kérdés is, hogy vajon a mérvadó társadalomelméleti sémák szerinti sémákból, mint előfeltevésekből következő „extrémitás”, az jelenségként mennyiben kivételes és ritka? És megeshet, hogy nem is feltétlenül annyira ritka, kivételes és rendkívüli, hogy azokat empirikusan is extrémitásnak kell tekinteni. Ha ez a helyzet, akkor az ilyen tapasztalatok alapján az előfeltevések helytállóságát is meg lehet kérdőjelezni.

Az alábbiakban kifejtett részletezéssel a kutatásnak ez lehet az egyik legfontosabb koncepcionális és elméleti kerete, kitüntetett elemzési szempontja.

\section{A NEM SZÁNDÉKOLT, „KIREKESZTETT” ÉS HÁTRÁNYTÉNYEZŐ, A MOBILITÁS KUDARCAKÉNT ÉRTELMEZETT IMMOBILITÁS, AMI OLYKOR A NARRATÍV INTERJÚK ISMERETELMÉLETI CSAPDÁJA - AMIT ÉRDEMES ELKERÜLNI}

A magatartási közgazdaságtan atyamestereinek (Kahneman és Tversky) egyik kiinduló rácsodálkozása volt az, hogy még statisztikában járatos társadalomkutatók sem szeretnek, tudnak a valószínűségekkel (ha úgy tetszik, az emberi döntéseken kívül álló tendenciákkal, pláne mázlikkal és balszerencsékkel) kalkulálni. Az ember jobban szereti oksági összefüggésekbe rendezni ismereteit, mint csupán a korrelációs jellegű együttjárások statisztikus trendjeibe illeszkedőnek beállítani akár saját, akár mások döntéseit, akár a megismert, de a döntési befolyáson kívül álló jelenségeket. Szeretünk úgy tenni, mintha az időben korábban megtörtént események automatikusan okai is lennének az okozatként értelmezett később megtörténteknek. Sőt, hogy az időrendbe rendezett események, azok mintegy az ok-okozatok sorozata lenne; a végső kimenet, az pedig ezen „oksági szekvenciák” végeredménye lenne. (Mint a matematikai példák lépésről lépésre haladó végeredményének a kiszámítása.)

Az okságokba rendezés iránti vonzalom (amely egyaránt jellemzi az interjúert is és az interjúalanyt is) komoly veszély minden élettörténetet (munkatörténetet, tanulástörténetet, családtörténetet stb.) feldolgozó kutatásra. De különösen az, részben az interjús, narratívákra épülő kutatások esetében, és még nagyobb veszély akkor, amikor épp szándékokat, motívumokat, indítékokat akarunk feltárni. Könnyü abba a saját előfeltevéseinket megerősítő csapdába belesétálni, hogy minden megta- 


\section{TEMATIKUS TANULMÁNYOK - Községekben élő immobil fiatalok}

pasztalt körülmény, minden fontos döntés, minden jelentős életesemény okszerúen következik az általunk keresett motívumokból és az életútról korábban feltárt körülményekből. Pedig nem. Mondjuk, egy állás betöltésének olykor lényegesebb indítékának tûnik fel utólag a hasonló munka megszerzésére irányuló személyes törekvés, mint az, hogy épp akkor, épp ott volt megüresedés, amelyről véletlenül épp alanyunk keresztanyja tudott előbb, minthogy meghirdették volna az állást, de, aki éppen véletlenül a sógornője is az állás betöltéséről döntő munkaadónak stb. Az olykor el sem mesélt véletleneknek olykor jelentősebb a történeteket (esetünkben a helyben maradást) befolyásoló ereje, mint a megélt és elmesélt korábbi életeseményeknek, felmerült gondolatoknak vagy vágyaknak.

Épp e nehézséggel szembesülve jelent különös, és nagy óvatossággal kezelendő intellektuális kalandot a mégiscsak létező szándékok, motívumok, indítékok kihámozása az interjúkból.

Ezeket az indítékokat a legnehezebb kihámozni az interjúkból, de az elemzéseknél muszáj a „kis jelzéseket” is kellő súllyal értelmezni e szempontból. A helyzet az, hogy az emberek nem szívesen cipelik magukkal a megélt feszültségeket és kudarcokat, hogy a felejtés képessége épp úgy része az egészséges emberi elme működésének, mint az emlékezésé. (Emiatt is szörnyü lehet autistának lenni: ők mindenre emlékeznek, és nem képesek felejteni.) A kognitív disszonancia redukciója, az emlékezésnek a feszültségektől való meg- és felszabadítása eléggé természetes emberi tulajdonság.

Történetünkben, amely nem szociálpszichológiai, hanem mobilitási/immobilitási kutatás, e körülménynek döntő magyarázó jelentősége lehet életpályák értelmezésében és magyarázatában.

Nagyon leegyszerűsítve: a mobilitási kudarcok és feszültségek megélése, megtapasztalása egyfelől erős „elhallgatási késztetéseket” égethetett bele az interjúalanyok megélt történeteibe; másfelől, az utólag, az emlékezésekben és elmesélt történetekben a feszültségektől megszabadított mobilitási kudarcok „rózsaszínűre festhetik” az immobilitás „sikertörténeteit” is. Az immobilitás élhető világa minden hátrány ellenére sokkal szebbnek fog tűnni akkor, ha valaki korábban megélt mobilitási kudarcokat és csalódásokat.

Emiatt, még a bizonytalan, a háttérből felfeslő mobilitási kudarcoknak is érdemes kellő súlyt adni az esettanulmányok során. 
TEMATIKUS TANULMÁNYOK - Községekben élő immobil fiatalok

\section{Az intencionális, szándékolt immobilitás indítékai és motívumai}

\section{SZÁNDÉK ÉS HASZON}

A XX. század második felének társadalomtudományi, szociológiai és közgazdasági gondolati sémáját igen erősen uralta az a „racionális döntéselmélet”, amelynek leginkább kifejtett szociológiai programját Jon Elster fektette le. ${ }^{5}$ Elster fő mondandója az, hogy az emberi cselekedeteket (ritka kivételtől eltekintve) szándékoltnak (,intencionálisnak") kell tekinteni, és a cselekedetek szándékainak magyarázataként dominánsan a racionális érdekeket kell magyarázatként figyelembe venni. Ha az emberek szándékosan döntéseket hoznak, akkor e szándék, az (ismét, ritka és extrém kivételektől eltekintve) nem lehet más, mint a lehetséges legnagyobb hasznok legnagyobb valószínűséggel történő realizálása (avagy ennek ellentételeként, a legnagyobb veszteségek legnagyobb valószínűséggel történő elkerülése).

Az elmúlt évtizedek társadalomtudományi gondolkodása, sőt, maga Elster is jellemzően szakított ezzel a túlzóan leegyszerűsítő, és elég normatív (sőt, gyakran doktriner) látásmóddal. Ami attól normatív és doktriner, mert túllép a leíró és magyarázó kereteken, és igencsak azt sulykolja: ha nem vagy racionális, és nem az érdekeidet követed, akkor hülye vagy, racionálisnak kell lenned.

Az immobilitás szándékait és motívumait kereső feldolgozásnak e szempontból kényes egyensúlyt kell tartania. Kétségtelen és letagadhatatlan tény az, hogy létező és erősen befolyásoló emberi motívum az önző érdek, az anyagi hasznokra törekvés, és ezen érdekvezérelt motívumokat meg is kell próbálni kimutatni, „kihámozni” az interjúkból. (Ismét fel kell hívnunk a figyelmet az előfeltevések torzító hatására: a „legitim” és konvencionális beszédmód gyakran, épp a fenti normatív tartalmak miatt, szereti verbálisan érdekké és haszonná transzformálni a nem ilyen természetű indítékokat és szándékokat is, sőt, a tudatos döntéstől és befolyásolásoktól mentes „véletlen” eseményeket is.).

Tehát, az elemzéseknek nemhogy ki kell térniük a nem racionális és nem haszonelvű szándékok feltárására is, hanem sőt. Sejtésként épp az lehet az egyik legfontosabb hipotézis, hogy bár a racionális haszonelvú gondolkodási sémában a mobilitás a „normális és természetes” döntés és következtetés - az immobilitás magyarázatai között viszont könnyen lehet, hogy épp a nem ilyen természetú céloknak, szándékoknak lehet befolyásoló motiváló erejük, hatásuk.

\footnotetext{
${ }^{5}$ A magyarra „A társadalom fogaskerekei” címen megjelent, eredetileg „Bolts and Nuts” (Csavarok és anyacsavarok) című könyvének 2007-es újrakiadásában azután jelentősen felülvizsgálta korábbi alapvetéseit, de ez mellékszál. Lásd: Elster, J. (2001): A társadalom fogaskerekei - Magyarázó mechanizmusok a társadalomtudományokban. Osiris-Századvég, Budapest, illetve: Elster, J. (2007): Explaining Social Behavior: More Nuts and Bolts for the Social Sciences, Cambridge University Press
} 


\section{TEMATIKUS TANULMÁNYOK - Községekben élő immobil fiatalok}

\section{A MOTÍVUMOK ÖSSZETETTEK, SOKFÉLÉK, NEM „TISZTÁK” - KEVEREDNEK EGYMÁSSAL}

Polányi gazdaságszemléletének kulcseleme a düh és indulat a „formális” gazdaságszemlélet kizárólagosságával szemben (Polányi 1976). Ő az embert már gazdasági, mondjuk inkább így: „megélhetési” céljainak megvalósításában is bonyolult és öszszetett képződménynek tekinti. Aki, a piaci „értékarányos cserék” világán kívül is, olykor maga csinál meg ezt-azt a háztartásában (szereti a családtagjait megvendégelni a saját maga főzte ebédre, szereti maga fürdetni a saját koszos kölkét stb.), olykor viszonossági kötelmeinek megfelelően „reciprok” műveletekbe vonódik be (karácsonykor meg születésnapokon megajándékoz minden féle népeket, akik ezt jellemzően viszonozzák, ha nem is ugyanakkor, hanem az ajándékozó következő születésnapján), olykor összedob és szétoszt dolgokat (a szalonnasütéshez más hozza a szalonnát, a kenyeret, meg a hagymát, nem beszélve a pálinkáról és a borról, stb.) Ezek a motívumok nem kizárólagosak, hanem sőt, összeállnak egyfelől emberek-háztartások „komplex” gazdálkodásává (amiben, hát karácsonykor sokan kiköltekezik ingüket-gatyájukat az ajándékokra, ami piaci értelemben nem túl racionális, de, „benne van a pakliban”; másfelől, sajátos szokásrendeké és rögzült intézményekké. Akkor is, ha nem írásban rögzítik az intézmények szabályait - de, az ember ismeri a tanítónéni pedagógusnapi virágcsokrának meg az orvos hálapénzének a „Szabályozott és intézményes kereteit".

Polányi nem beszélt arról az „életről”, amelybe beágyazódnak a különféle gazdasági magatartások, de, már a szubsztantív gazdaság összetett, sokszínű és bonyolult komplexitásának az elemzése is eléggé nagy ívű programja volt. Nekünk itt egy kicsit bonyolultabb a feladatunk ennél is: az „élet” motívumainak sokszínűségét és összetett komplexitását kell valamennyire értelmeznünk legalább annyiban, hogy a falusi immobilitás jelenségét képesek legyünk leírni és magyarázni.

Az alábbiakban néhány, a motívumról szóló analitikus hipotézist vetek fel tehát arról, hogy milyen, egymással összefonódva kavarodó, nem tisztán, de mégis érvényesülő szándékok és motívumok vezetnek a maradáshoz, a szándékos és tudatos immobilitáshoz.

\section{a) Racionális motívumok}

\section{(„Bejáró racionalizmus”)}

A tudatos faluban maradás indítéka lehet az, hogy a város könnyü, gyors és kényelmes elérhetősége mellett kombinálhatók a városi és falusi lét előnyei; illetve, a kombinációk révén csökkenthetők mind a városi, mind a falusi lét hátrányai.

A faluból a városba bejáró racionalizmus lehet „egyénileg megkomponált ügyes, trükkös kombináció” is, de nem szabad megfeledkezni arról, hogy e racionalitásnak 


\section{TEMATIKUS TANULMÁNYOK - Községekben élő immobil fiatalok}

erősek a társadalmi, társadalomföldrajzi meghatározottságai. Ha Kovách Imrétől (2012) merítve egy másik, a településszerkezetre a Chicago-i városszociológiából eredő koncentrikus köreinek gondolatát akarnám itt az egyszerűség kedvéért kiemelni, akkor a város körüli kvázi-koncentrikus köröket úgy írhatnánk le, hogy:

- a legbelső kör az maga a város.

- E körül egy a várossal összenőtt max. 5-10km. Körben a lokális „Rózsadombok" kertvárosi világa, ahol csend van, nagyok a kertek és a házak - de minden városi lehetőség (üzleti, közszolgálati, kulturális, vallási, bármi) épp úgy elérhető, mint a város bármely részéből. A „zöldövezeti kertvárosok” olykor közigazgatásilag a város városrészei, de gyakran önálló települések, „falvak” - ahol nemcsak lehet, de igen magas presztízsű is „ottmaradni”, immobilnak lenni.

- Ezen kívül, mondjuk 1 órányi beutazási időhatárokon (kb. 30-60km sugarú koncentrikus körig) vannak azok az „alkalmazotti ingázó övezetek”, ahonnan már leginkább a munkalehetőségek és pénzkereseti lehetőségek érhetők el a városban, a többi szolgáltatás, szolgálat, lehetőség már jellemzően helybeli. Ebben az „osztott bejáró” logika fenntartásában nagy szerepük van a térség települési önkormányzatainak. Bár a pénz, az emberek keresetének döntő hányada a városból jön, ám ahhoz, hogy az emberek a pénzüket ott akarják elkölteni, ahhoz viszonylag jó közszolgálatoknak (iskola, orvos, akár szakorvos is), urbanizációs infrastruktúrának (út, tömegközlekedés, víz, gáz, csatorna, szemétszállítás stb.), sőt, használható kereskedelemnek és bolthálózatnak is múködnie kell, enélkül az emberek beljebb fognak költözni.

- A legkülső körből gyakorlatilag nem, vagy csak rendkívüli események (pl. kórház) kapcsán érhető el a város. Nagyon gyakran csak ez a semmi közepén található „elmaradt kistérségi falu” jelenik meg az emberek falusról szóló képzeteiben, ahonnan valóban, gyakorlatilag sem a városi munkalehetőségek, sem a város „szolgáltatási” lehetőségei nem, vagy csak alig érhetők el.

A fenti leegyszerűsített sémában nyilvánvaló, hogy a „bejáró racionalitás” motívumaival leginkább a „rózsadombi kertvárosi”és az „alkalmazotti ingázós” sávokban fogunk gyakrabban találkozni - nem kizárva azt, hogy ott sem feltétlenül, és máshol is lehetnek „trükkös egyéni lehetőségek” a földrajzi távolságok könnyű és kényelmes áthidalására, a városi és falusi lét racionálisan hasznos kombinációjára.

\section{(„Költség-haszon egyenleg-racionalitás” motívumai)}

Az emberek nemcsak a pénz, a jövedelem megkereshető mennyiségének maximalizálása hajtja racionális érdekként, hanem az is, hogy mihez tudnak hozzájutni a pénzükön. Racionális érdek lehet olyan helyen élni, ahol igaz, hogy kisebb jövedelemre lehet szert tenni, mint a városban, de e különbségnél még nagyobb a megélhetéshez 


\section{TEMATIKUS TANULMÁNYOK - Községekben élő immobil fiatalok}

szükséges összeg, még olcsóbban lehet megélni annál, mint amennyivel kisebb a megszerezhető jövedelem. Ezt a fajta „kevesebb pénzből, de még olcsóbban” racionalitás leginkább a lakásköltségek kapcsán merülhet fel: az olcsón megszerezhető falusi lakástulajdon (amelynek bérleti díja sincsen, eladósodni sem kell föltétlenül annyira, olykor olcsóbbak a rezsik is stb.) költségtakarékossága könnyen jelentősebb lehet annál, mint amennyivel többet lehet keresni a városban. Mindez különösen gyakran előforduló motívum lehet a központi bérszabályozásban működő állami/közszférában, ahol a rögzített bértarifák mellett kisebbek a keresetek közötti különbségek a város és a falu között, mint az üzleti szektorban.

\section{(Lokális funkcionális ritkaság és hasznosság magas jutalma)}

A klasszikus rétegződéselméletekben (Parsons, Davis - Moore, Tumin, Lenski stb., sőt, az ezekből kinővő olyan elit-elméletekben, mint C.W. Mills) a társadalmi egyenlőtlenségeket azzal szokás magyarázni, hogy a ritka és különösen fontos társadalmi funkciókat betöltő embereket a társadalom magasan jutalmazza. Ebben a narratív keretben racionális érdeke lehet ottmaradnia a falujában annak, akiknek a település boldogulásához való funkcionális hozzájárulását a település magasan (az országosan szokásosnál magasabban) honorálja, jutalmazza. Efféle extra haszonnal honorált funkcionális hasznosság lehet pl. az (idegennyelv-tudással megtámogatott) projekt- és pályázat-képesség, vagy az interneten való közösségi megjelenés számítástechnikai tudása, netán hasznos politikai kapcsolatokkal való rendelkezés.

\section{b) „Szubsztantív gazdasági racionalitás” motívumai}

Egy „ortodox közgazdasági szemléletben” (ilyenek pl. Sik Endre ${ }^{6}$ elemzései) Polányi szubsztantív gazdaságának piacon kívüli technikái és szokásrendjei (önellátás és „háztartási produktivitás”, viszonosságok/reciprocitás és közösködések/redisztribúció) alapvetően mint pénzkímélő, pénzt helyettesítő, a piacok inadekvátságát kompenzáló gazdálkodási formák jelennek meg. Igen egyszerűen: ha ilyen lehetőségek (ideértve gazdálkodási vagyont, nemcsak a termelésben, hanem raktározásban, logisztikában, kamrában és veremben, ehhez való „tudásban”, kultúrában, valamint kapcsolati hálókban, munkamegosztási szokásrendekben stb. is) rendelkezésre állnak, akkor ezzel „olcsóbbá” lehet tenni az életet, kevesebb pénzből is meg lehet élni. E koncepciónak különös népszerűsége volt a rendszerváltás előtti „második gazda-

${ }^{6}$ Lásd pl.: Sik E. (2017): Néhány gondolat a háztartásról mint a gazdaság egy szereplőjéről, 2017, in: KSH: Háztartási munka, önkéntes munka, láthatatlan munka, I., KSH Konferenciakötet, www.ksh.hu/ docs/hun/xftp/idoszaki/pdf/lathatatlan_munka_1.pdf , illetve: Sik E. - Szép K. (2003): A háztartási termelés értéke a mai Magyarországon. A háztartási szatellitszámla 2000. évi kísérleti számításai. Műhelytanulmányok, KSH. 


\section{TEMATIKUS TANULMÁNYOK - Községekben élő immobil fiatalok}

ság” feltárásában, de mára (alapvetően a TSZ-ek integráló szerepének kiesésével) az árutermelésben való piaci alternatívákkal szemben nagyobb jelentőségre tettek szert a szolgáltatások vásárlását kiváltani/pótolni képes alternatív technikák. Olyanok, mint a „baráti áron” szervizelt autók, amit más előnyökkel (akár bennfentes információkkal, kapcsolatok mobilizálásával, protekciókkal) lehet viszonozni.

Vélelmezhetően e „szubsztantív eszköztár” jelentőségét felnagyítja a szülőkkel és más rokonokkal való gazdálkodási szimbiózis előfordulása, és még ennél is inkább a gyereknevelésben a nagyszülők intenzív szerepvállalása (elmenni a kölökért az óvodába, utána megkajáltatni, akár ott is altatni, ha program van estére stb.).

\section{c) „Torzultan racionális" motívumok}

Már az előző megfontolások is beleágyazódnak egyfajta „torzult”, paraszti gyökerű racionalitásba, amelyben az idő, a munka, a munkaidő nem kalkulálódik „piaci értéken” (vagy még inkább: sehogyan sem), és az „élet a munka” mentalitás teszi pénzt kiváltó/helyettesítő piaci értelemben is „racionálissá” a szubsztantív gazdálkodási formákat.7 Nyilvánvaló az, hogy hasonló falusi/paraszti kulturális gyökerei vannak más „torzítottan racionális” motívumoknak is, de ilyen torzulásokat szép számban írnak le a modern magatartási közgazdaságtan elméletei is. Vélelmezhetően ezek közül a legjelentősebb torzultan racionális motívum a Kahneman és Tversky által „loss aversion” (a veszteségekkel szembeni averzió, a veszteségek elkerülését a hasznok realizálásánál előbbre helyezett igyekezete) (Kahneman. 2013). Profánabbul megfogalmazva: az, ami megvan, azt nem lehet pocsékba menni. Ez az olykori görcsös ragaszkodás a hagyományos falusi/paraszti gondolkodásban a földhöz való ragaszkodás (nemcsak a tulajdonláshoz, hanem a múveléshez is: ha van föld, akkor azon valamit termelni kell), de hasonló veszteségkerülő torzult racionalitás köthet embereket a házhoz, a szülők által vitt bolthoz, az iparhoz is.

Sok szempontból e torzultan racionális ragaszkodások feltárása adhatja az egyik legfontosabb választ arra a kérdésre, hogy mennyiben élnek tovább a mai fiatalokban a hagyományos paraszti mentalitás és kultúra értékei, beidegződései.

\section{d) Társadalmi ismertség, elismertség, státuszteremtés motívumai}

Ezek az immobilitási indítékok, motívumok már semmilyen értelemben nem tekinthetőek a hasznok realizálásához füződő „önző érdeknek”, viszont, vélelmezhetően akár még az előzőeknél is fontosabb indítékokat jelentenek a faluban maradáshoz.

${ }^{7}$ Ezt a gondolatot számos helyen kifejti Fél Edit és Hofer Tamás, legtisztább elméleti keretekben lásd: Fél E. - Hofer T. (1997): Arányok és mértékek a paraszti gazdálkodásban. Balassi Kiadó. http://mek.oszk. hu/04900/04950/04950.pdf 


\section{(Kötelem és hüség)}

Sokak számára a faluból való elköltözés, a mobilitás - az egy igazából fel sem merülő lehetőség, az arról való ábrándozás, az legfeljebb olyan, mint egy regény vagy egy film történetébe való képzelgő beleélés. Az ember olykor egyszerúen odatartozik és pont. Felelőssége, dolga, egyfajta „adóssága” és „hűsége” van a szüleivel, esetleg más rokonaival szemben (pláne, ha öregek, és segítségre szorulnak), oda kötik a barátságok, érzelmi kötelékek, az (érdekes, hogy miképpen... de) bárhogyan értelmezett közösséghez tartozás kötelmei. Ezek a kötelmek kevésbé a hasznokról, a személyes előnyökről szólnak - sokkal inkább a kötelmeknek a kötelességek tartalmáról: muszáj itt maradnom, mert nekem itt dolgom van, ennyivel tartozom az enyémeknek.

Ezekről a kötelmekről nem feltétlenül illik beszélnie egy „modern és racionális fiatalnak", még a társadalomtudományban sincsenek e kötelmekre használt szokásos fogalmak és koncepciók - emiatt a kötelmek jellemzően nem érzelemként, habitusként, hanem „anyagias tartozásként” szoktak megfogalmazódni. Különösen jellemzőek az öregekkel szembeni segítési, gondozási kötelmek: az öregeknek fontos, de nehéz fizikai munkák elvégzésében, patika vagy más bevásárlás elintézésében, olykor tényleges gondozási feladatokban is.

Az interjúk feldolgozása során különösen érdekesek lehetnek azok a kötelmek, amelyek a diploma megszerzésének, a „kiemelkedésnek” a viszonzásaként jöhetnek elő, akár a falu egészével szemben, mint a falu életében fontos feladatok és funkciók betöltésének kötelme (ideértve az informális, pl. közösségszervezői kötelmeket is), illetve a még fiatalabbakkal, gyerekekkel (a közösségként a mi kölkeinkkel) szembeni kötelezettségek. Amelyek némiképp azonosak a gyerekeknek „kijáró”, a miénknél boldogabb holnap erkölcsi kötelmeivel is.

A kötelem és hűség koncepcionális kereteiben másképp értelmeződik a piacon kívüli „alternatív gazdálkodás” gyakorlata, mint ahogyan arról korábban szó esett. Nem a piaci részvétel kudarcainak és korlátainak kompenzálási készleteiként merülnek fel az önellátás, a viszonosságok és osztozkodások szokásrendjébe („intézményeibe") való illeszkedés, hanem: kötelemként. Az embernek rendben KELL tartania a portáját, nem verheti fel a gaz a földjét; az embernek el KELL mennie a temetésre és a lagziba is, és meg KELL táncoltatni a menyasszonyt, ahol oda KELL adni a jelentősebb értéket képviselő nászajándékot; és ha elromlott az autó, akkor a baráti áron vagy haveri segítségként megjavító szomszéd autószerelőhöz KELL vinni az autót, különben sértődés lesz a vége.

\section{(Ismertség és biztonság)}

Sokak számára a falu minden városi előnyt felülíró értéke és előnye az, hogy itt az emberek ismerik egymást, hogy számontartják egymást, hogy érzékelik azt, ha valakivel valami baj van és hiányzik az, ha bármikor és bárhova bárki „eltúnik”. Érték az, 


\section{TEMATIKUS TANULMÁNYOK - Községekben élő immobil fiatalok}

hogy itt nevük és arcuk van az embereknek - amit a város, különösen a „parvenü” gyüttment most érkezett számára biztosan nem tud nyújtani. Ismét, komoly verbalizálási problémát jelenthet annak a „pitiáner” értéknek a kimondása, hogy jó az, ha a boltos tudja, hogy a mi családunkban a sötétebbre sült kenyeret szoktuk szeretni pedig, bármily pitiánernek is tűnik, ez sokaknak nagyon fontos érték, és nagyon fontos motívum a maradásra.

Sok szempontból ezek az ismertségek, arccal való felismerhetőségek nem többek, mint a „szokás hatalma”, sőt, mint a váltásra való alkati képtelenség beismerése - ami miatt sokan szégyellik is bevallani azt, hogy mindezek a „konzervatív” értékek és szokások számítanak. Pedig az otthonosság, az egymásra utalt biztonság értékeiként és motívumaiként - sokaknak igencsak számítanak.

\section{(Elismertség, tekintély, befolyás, hatalom) ${ }^{8}$}

Sokak számára letagadhatatlanul a maradásra, az immobilitásra késztető indíték, motívum az, hogy, míg a városban ő csak egy arctalan, egyéniségétől megfosztott, gyüttment senki lehet, addig ő a saját falujában egy jegyzett, számontartott, egyéniségként rendkívüli és egyéni jelenségként elkönyvelt „valaki” lehet. Neki ebben a közegben olyan tudásai, munkaképességei, kompetenciái lehetnek, amelyeket a többiek hozzá rendelnek, neki tulajdonítanak, és ezek alapján, legalábbis bizonyos kérdésekben az ő szava számít, az ő véleménye befolyásol másokat, ennyiben a rendkívülisége még hatalmat is biztosít számára.

E kitüntetettségek gyakran dinasztikus alapúak (ő az apja fia/lánya, örökli a szülők megbecsültségét és tekintélyét), de még ezek híján is, különösen, ha magas végzettséggel tér vissza a falujába, akkor saját jogán is szert tehet efféle elismertségre, tekintélyre, befolyásra, hatalomra.

Az immobilitás vélelmezhetően egyik legfontosabb indítéka és motívuma ez lehet: neki a saját falujában van módja társadalmi státuszra, jogállásra, elismert és tisztelt szerepre szert tennie - ami gyakorta bőven ellensúlyozza akár azt is, hogy a városban (Pesten, külföldön) több pénzt kereshet.

\section{A kiegészítő adatok és másodlagos források interpretációjához néhány szempont}

Az elérhető kvantitatív adatok semmit sem mondanak arról, hogy mely immobilitási indíték és motívum milyen gyakran fordul elő. Sem általában, sem bizonyos leszűkített csoportok körében. Ezt a „nem tudást” érdemes legalábbis becslésekkel pótolni

\footnotetext{
${ }^{8}$ A téma elméleti hátterét gazdagon ismerteti a Stanford Encyclopedia of Philosophy szócikke: Iser, M. (2013): Recognition, Stanford Encyclopedia of Philosophy, https://plato.stanford.edu/index.html
} 


\section{TEMATIKUS TANULMÁNYOK - Községekben élő immobil fiatalok}

az interjúk elkészültének helyszínéről szóló statisztikai adatokkal, így a TEIR települési adataiból nyert impressziókkal.

Becslésről és impresszióról két okból muszáj beszélni.

Egyrészt, ennek statisztikai magyarázata van: miután nincsen „immobil alapsokaság”, ezért elvileg sem nagyon lehet elképzelni e nem-létező alapsokasággal megegyező összetételű „mintát” - és akkor még nem beszéltünk a ténylegesen lekérdezett és a spekulált „minta” elég súlyos torzulásairól. Statisztikai értelemben van elég sok fiatal, ami minden torzulás ellenére is, becslések megtételére a benyomások és sejtések szintjén kellő alapot ad.

A másik szükségszerű korlát az a statisztikai adatok szükségszerű információvesztése. Ami a motívumok és indítékok létezését megalapozó, minőségükben másoktól megkülönböztethető „kvalitatív” jelenségként kiolvasható az interjúkból (sztorikból, életeseményekből, emlékekből, nyelvi gesztusokból stb.) - az bizonyosan nem tehető meg a statisztikák aggregált adataiból. Amit meg lehet tenni afféle „közelíto és becslő" eljárásként, az az, hogy a statisztikai adatokat az interjúkból feltárt motívumokra utaló, azt sejtető, e sejtések alapján azoknak „impresszionistán megfeleltethető" információnak tekintjük, és ezek alapján teszünk mennyiségi becsléseket a motívumok előfordulásának gyakoriságára.

Mindezen statisztikai becslések szükségszerúen pontatlanok, jó esetben is csak nagyságrendekben képesek méreteket vagy belső arányokat jelezni.

A kutatás legfőbb értéke az, ha a faluban helyben maradás, a „semmi mobilitás nem történik" jelenségek értelmezéséhez az interjúk alapján olyan egyéni, családi, települési helyzetek, és olyan egyéni döntések és indítékok vázolhatóak, amelyek képesek magyarázni a megkérdezett fiatalok immobilitását.

\section{Konklúzió}

Bár az általános feltételezések szerint a falusiaknak, különösen a magasan képzett falusi fiataloknak érdemes elhagyni a falujukat, és a társadalmi mobilitásukkal öszszekapcsolódva földrajzi értelemben is mobillá válni - ez az általánosítás nem vezet szükségszerűen földrajzi mobilitáshoz, és ugyancsak nem feltétlenül kudarc az immobilitás. A fentiekben számba vettünk számos olyan indítékot, motívumot, közöttük anyagi érdekeket is - amelyek megfontolása józan, ésszerű döntésként vezet a maradáshoz, az immobilitáshoz.

E motívumok, indítékok tudatos döntésként való indoklása, igazolása, magyarázata számos kutatástervezési és módszertani nehézséggel jár - ugyanis az, ami közvetlenül megfigyelhető, hogy a fiatalok ottmaradnak, ahol voltak, hogy látszólag nem történik semmi, nem döntenek semmiről. Pedig, olykor a maradásnak ésszerű jó oka van, az immobilitás is tudatos, szándékolt döntés kimenete. 
www. metszetek.unideb.hu

\section{TEMATIKUS TANULMÁNYOK - Községekben élő immobil fiatalok}

\section{Irodalom}

Berkovits Gy. (1978): Világváros határában. Szépirodalmi Kiadó - Magyarország felfedezése,Budapest

Castells, M. (2005): A hálózati társadalom kialakulása I-III. Gondolat, Budapest

Elster, J. (2001): A társadalom fogaskerekei - Magyarázó mechanizmusok a társadalomtudományokban. Osiris-Századvég, Budapest

Elster, J. (2007): Explaining Social Behavior: More Nuts and Bolts for the Social Sciences. Cambridge University Press

Fél E. - Hofer T. (1997): Arányok és mértékek a paraszti gazdálkodásban. Balassi Kiadó, http://mek.oszk.hu/04900/04950/04950.pdf (Utolsó letöltés: 2019. 09. 06.)

Harcsa I. - Kovách I. - Szelényi I. (1998): The Hungarian agricultural 'miracle' and the limits of socialist reforms. In: Szelényi I. (ed.): Privatizing the Land. Rural political economy in post-communist societies. London, New York: Routledge and Kegan Paul

Iser, M. (2013): Recognition. Stanford Encyclopedia of Philosophy https://plato. stanford.edu/entries/recognition/ (Utolsó letöltés: 2019. 09. 06.)

Kahneman, D. (2013): Gyors és lassú gondolkodás, HVG Könyvek, Budapest

Kesselring, S. (2006): Pioneering mobilities: new patterns of movement and motility in a mobile world. Environment and Planning 2006/38, pp 269-279.http://www. unisa.edu.au/siteassets/episerver-6-files/global/eass/hri/pioneering-mobilities_kesselring-sven.pdf (Utolsó letöltés: 2019. 09. 06.)

Kolozsi Á. (2018): Mi Orbánék titka? (Interjú Kovách Imrével) Index, 2018. 03.26. https://index.hu/tudomany/2018/03/26/az_orban-rendszer_mukodese_kovach_imre_interju/

Kovách I. (2012): A vidék az ezredfordulón - A jelenkori magyar vidéki társadalom szerkezeti és hatalmi változásai. Argumentum - MTA TKSZI, http://mek.niif. hu/12700/12727/12727.pdf (Utolsó letöltés: 2019. 09. 06.)

Kovács, K (szerk.) (2016): Földből élők: Polarizáció a magyar vidéken. Argentum Kiadó, http://www.regscience.hu:8080/xmlui/handle/11155/1275 (Utolsó letöltés: 2019. 09. 06.)

KSH: Az ingázás kiemelt célpontjai, KSH 2016.április, http://www.ksh.hu/docs/ hun/xftp/idoszaki/pdf/ingazas.pdf (Utolsó letöltés: 2019. 09. 06.)

Polányi K. (1976): Az archaikus társadalom és a gazdasági szemlélet. Gondolat - Társadalomtudományi Könyvtár

Putnam, R. D. (2000): Bowling Alone. Schuster \& Schuster, New York 


\section{TEMATIKUS TANULMÁNYOK - KöZségekben élő immobil fiatalok}

Sik E. - Szép K. (2003): A háztartási termelés értéke a mai Magyarországon. A háztartási szatellitszámla 2000. évi kísérleti számításai. Műhelytanulmányok, KSH

Sik E. (2017): Néhány gondolat a háztartásról mint a gazdaság egy szereplőjéről. In: KSH: Háztartási munka, önkéntes munka, láthatatlan munka, I. KSH Konferenciakötet, www.ksh.hu/docs/hun/xftp/idoszaki/pdf/lathatatlan_munka_1.pdf (Utolsó letöltés: 2019. 09. 06.) 